\title{
KVALITETA ŽIVOTA MLADIH IZ VUKOVARSKO- SRIJEMSKE ŽUPANIJE U UVJETIMA SUVREMENE DEMOGRAFSKE KRIZE
}

\author{
Mateo Žanić, Geran Marko Miletić i Ivana Bendra
}

Institut društvenih znanosti Ivo Pilar

Područni centar Vukovar

J. J. Strossmayera 25, 32000 Vukovar

e-mail: Mateo.Zanic@pilar.hr

\begin{abstract}
Sažetak
Rad je pisan na temelju rezultata istraživanja u kojem su sudjelovale učenice $i$ učenici trećih $i$ četvrtih razreda srednjih škola na području Vukovarsko-srijemske županije. Utvrdeno je da bi, premda su učenici dominantno zadovoljni svojim životom, kao i pojedinim dimenzijama kvalitete života, velik broj njih, čak $64,2 \%$, želio nakon završetka školovanja živjeti negdje izvan Vukovarsko-srijemske županije. Rezultati sugeriraju da se uzrok tome može tražiti u izuzetno niskoj percepciji mogućnosti zapošljavanja u županiji kao i niskom povjerenju u važne institucije. Potvrdena je pritom hipoteza da postoji povezanost između ocjene kvalitete života i želje da se nakon završetka školovanja nastavi živjeti na području županije, budući da su ispitanici koji su redovito dimenzije kvalitete života ocjenjivali višima pokazali veću želju da u budućnosti žive na području županije.
\end{abstract}

Ključne riječi: kvaliteta života, mladi, Vukovarsko-srijemska županija, migracijska očekivanja, demografska kriza

\section{UVOD}

Kvaliteta života je višedimenzionalan pojam koji se različito koristi u različitim znanstvenim disciplinama. Kada su u pitanju društvene i humanističke znanosti koncept se posebno koristio u ekonomiji, psihologiji, geografiji i sociologiji. U ekonomskoj znanosti kao ključni indikatori kvalitete života koriste se ekonomsko blagostanje, gospodarski rast te životni standard stanovništva (Mrvica Mađarac, 2017). Od interesa su stoga pokazatelji kao što su visina dohotka ili mogućnosti zadovoljenja potreba kroz potrošnju usluga i dobara. U geografiji i sociologiji pak kvaliteta života istražuje se primjenom različitih indikatora kojima se nastoje utvrditi njezine prostorne i društvene varijacije te poboljšati rezultati javnih politika (Karajić, 1992; Slavuj, 2012b). Premda nije korišten sam pojam, istraživanja koja se mogu povezati s kvalitetom života u sociologiji su provođena još 1918., kada su istraživani uvjeti života obitelji mjereni različitim dimenzijama. Interes za razvijanjem društvenih varijabli za mjerenje nacionalnog blagostanja osobito 
je bio istaknut 60-ih godina dvadesetog stoljeća kada se tom temom bave i značajni teoretičari poput D. Bella i M. Olsona (Ferriss, 2004). Interdisciplinarnost koja je pratila ovaj pojam kao i relativno duga tradicija istraživanja povezanih $s$ njim učinili su ga prilično neodređenim.

Tako bi široko definirana kvaliteta života mogla uključivati sve ono s čime se ljudi susreću u svakodnevnom životu. Od potreba za radom, preko održavanja zdravlja do pitanja stanovanja, školovanja te zadovoljavanja kulturnih potreba.

Teškoće $\mathrm{u}$ istraživanju kvalitete života proizlaze i iz različitog vrednovanja i usklađenosti subjektivnih i objektivnih indikatora putem kojih se ovaj koncept mjeri. Istraživanja usmjerena na objektivne indikatore nastoje utvrditi precizne podatke koji bi trebali razlikovati dijelove nekog područja ili neke populacije prema jasno utvrđenim kriterijima: primjerice visine plaća ili posjedovanja određenih predmeta. Nasuprot statističkim podacima i usredotočenosti na objektivno mjerljive pokazatelje, istraživanja subjektivnih indikatora u prvi plan stavljaju pojedince koji sami procjenjuju pojedine elemente kvalitete života. Stoga ,temelj subjektivnih pokazatelja čine mjerenja psiholoških stanja pojedinca, odnosno njihovih vrijednosti, stavova, vjerovanja, aspiracija, zadovoljstva i sreće“ (Slavuj, 2012b:81).

Tijekom godina počeli su se razvijati i složeniji načini istraživanja koji uzimaju u obzir i subjektivne i objektivne indikatore, a pojavio se i niz instrumenata kojima se nastoji u globaliziranom svijetu vršiti usporedbe kvalitete života pojedinih država, regija i gradova (Slavuj, 2012b; Gottdiener i Hutchinson, 2011; Eurofound, 2014).

Sve to vrši dodatni pritisak na lokalne sredine da unaprijede elemente koji mogu doprinijeti kvaliteti života njegovih stanovnika. Naime, u slučaju da nije moguće zadovoljiti neke od potreba niti u mjestu stanovanja ili rada, niti u bližem okruženju „struktura svakodnevnice je ozbiljno narušena, pa se ona otežano održava ili, češće, reducira" (Seferagić, 1993:229).

U suvremenim okolnostima kada se intenziviraju migracijski procesi to se može pokazati ozbiljnim problemom, budući da se zbog nezadovoljstva postojećim aspektima života ljudi lakše mogu odlučiti na napuštanje sredine u kojoj stanuju. Dok se prema službenim podacima broj migranata konstantno povećava, ostaje otvorenim pitanje razloga, načina i motiva migriranja različitih populacija. Zbog velikog porasta migracija kao i promjena koje se uočavaju u konturama modernosti neki sociolozi ustvrdili su da dolazi do pucanja veza između stanovništva i prostora (Beck, 2001). Ljudi se prema tom shvaćanju sve lakše odlučuju za migriranje jer su se promijenili institucionalni i vrijednosni okviri koji usmjeravaju njihovo djelovanje. Pokazuje se također da nešto veću sklonost migriranju pokazuju visokoobrazovani, studenti i nezaposleni (Božić i Burić, 2005). Migracijske bilance pojedinih država se, međutim, bitno razlikuju te postoje one koje dugoročno imaju pozitivan migracijski saldo i one čiji je migracijski saldo negativan. Tako većina zapadnoeuropskih zemalja ima pozitivnu migracijsku bilancu, a osobito one $s$ visokim životnim standardom koji je povezan $s$ visokom stopom ekonomskog rasta i višom stopom zaposlenosti. Među takve zemlje spadaju Belgija, Švicarska i skandinavske zemlje koje razvijaju migracijske politike s ciljem „uvoza“ „radne snage koja, prema broju i 
strukturi, napose strukturi prema djelatnosti, zanimanju i obrazovanju, odgovara njihovoj potražnji za radnom snagom" (Wertheimer-Baletić, 2018:24). Pozitivan migracijski saldo je od velike važnosti i za zemlje poput Italije i Njemačke koje tako bilježe porast ukupnog broja stanovnika usprkos prirodnom smanjenju, dakle negativnoj stopi prirodnog „prirasta“ (Wertheimer-Baletić, 2018). Suprotno od većine zapadnoeuropskih zemalja Republika Hrvatska od 1990. konstantno bilježi smanjenje broja stanovnika, a na koje posljednjih godina snažno utječe i migracijska depopulacija. $S$ obzirom na razmjere negativnih demografskih trendova postalo je opravdano govoriti o demografskoj krizi s kojom se država susreće (Živić, 2017). Uz negativan migracijski saldo Hrvatska bilježi i ubrzan proces starenja stanovništva pa se za društveni i gospodarski razvoj osobito problematičnim navodi iseljavanje populacije mladih (Pejaković, 2016).

Mada se u znanstvenom diskursu razdoblje mladosti ne definira na isti način, odnosno varira i obično se određuje kao razdoblje od 15. do 24., 29. ili 34. godine, ističu se različita obilježaja koja su karakteristična za ovu populaciju (Ilišin i sur., 2013). Smatra se, primjerice, da je položaj ove populacije u suvremenim društvima osobito izazovan budući da bi se ona trebala integrirati u šire društvene odnose te istovremeno biti pokretač razvoja u ubrzano mijenjajućim društvima. Taj položaj osobito je težak u zemljama koje po različitim pokazateljima imaju periferan položaj u Europskoj uniji, a još teži za one regije unutar tih država koje imaju loše gospodarske pokazatelje te neke zabrinjavajuće društvene pojave. Intenziviranje migracijskih procesa tim područjima donosi nove probleme među kojima se osobito ističe onaj vezan uz zadržavanje mladog stanovništva. Pitanje koje se stoga postavlja je čime to građani Hrvatske, osobito mladi nisu zadovoljni i što ih navodi na odluku da napuste Hrvatsku i emigriraju u druge zemlje. Drugačije rečeno, postoji li povezanost ocjene kvalitete života i očekivanja od budućnosti, osobito odluke vezane za migriranje. Da se radi o važnoj temi sugerira i činjenica da se u hrvatskoj znanstvenoj zajednici posljednjih godina znatna pažnja pridavala istraživanjima koja se bave i kvalitetom života i planovima vezanim za budućnost u Hrvatskoj ili inozemstvu (Slavuj, 2012a; Eurofound, 2014; Relja i sur., 2015; Ilišin i sur., 2013; Lajić i sur., 2018; Peračković i Rihtar, 2016). Naslanjajući se na tu tradiciju, ovaj se rad usredotočio na povezanost (ne)zadovoljstva mladih kvalitetom života s njihovom eventualnom namjerom za promjenom mjesta življenja.

\section{DRUŠTVENI I DEMOGRAFSKI PROCESI U VUKOVARSKO- SRIJEMSKOJ ŽUPANIJI}

U Županijskoj razvojnoj strategiji 2007-2013. kao jedan od četiri dugoročna cilja Vukovarsko-srijemske županije navedeno je sljedeće: „poboljšanje kvalitete života kroz očuvanje prirodne i kulturne baštine, zdravlja i socijalne uključenosti“ (Čengić, 2012:462). $\mathrm{U}$ istom dokumentu navedeni su međutim i brojni nedostaci koji bi mogli utjecati na kvalitetu života stanovnika, kao primjerice nedovoljno kvalitetno upravljanje otpadom, opadanje kvalitete dostupnih zdravstvenih usluga ili nedostatak knjižnica. Kao prijetnje 
navedeni su procesi depopulacije te slaba konkurentnost gospodarstva. Analize kvalitete života u županiji, dakako, ne mogu zanemariti brojne negativne čimbenike koje su za sobom ostavila ratna razaranja na prostoru županije. Puni suverenitet Republike Hrvatske nad dijelom prostora županije ostvaren je tek 1998., a pokazat će se da tijekom godina, međutim, prostor županije nije uspio zadobiti očekivani gospodarski razvoj. Naime, pokazuje se da je 2014. gospodarstvo županije činilo oko $2 \%$ od ukupnog hrvatskog gospodarstva, dok je prije 1991. ono sudjelovalo u nacionalnom gospodarstvu s oko $4 \%$. Shodno tome, iznos prosječne plaće u županiji je znatno niži od iznosa prosječne plaće u Republici Hrvatskoj (Mrvica Mađarac, 2017).

Da Vukovarsko-srijemska županija razvojno zaostaje u odnosu na ostatak Hrvatske razvidno je i iz Tablice 1, u kojoj su prikazane vrijednosti indeksa razvijenosti za sve hrvatske županije. Sam indeks razvijenosti administrativni je alat za ocjenjivanje i razvrstavanje jedinica lokalne i područne (regionalne) samouprave u Republici Hrvatskoj po dostignutom stupnju društveno-gospodarskog razvoja (Ministarstvo regionalnoga razvoja i fondova Europske unije, 2018). Analitički gledano, riječ je o kompozitnom pokazatelju sastavljenom od ponderiranih prosjeka više osnovnih društveno-gospodarskih pokazatelja. Konkretno, u jednadžbu za izračun indeksa razvijenosti uključeni su: 1) prosječni dohodak po stanovniku, 2) prosječni izvorni proračunski prihod jedinice područne samouprave po stanovniku, 3) stopa nezaposlenosti (omjer broja nezaposlenih i zbroja svih zaposlenih te nezaposlenih osoba na području pojedine jedinice područne samouprave), 4) opće kretanje stanovništva (omjer usporedivog broja stanovnika jedinica područne samouprave u posljednjem dostupnom desetogodišnjem razdoblju), 5) stopa obrazovanosti stanovništva (postotni udio stanovništva sa završenim visokim obrazovanjem u ukupnom stanovništvu, u dobi između 20 i 65 godina, na području jedinice regionalne samouprave) i 6) indeks starenja (postotni udio stanovništva u dobi 60 i više godina u odnosu na broj stanovnika u dobi do 19 godina).

Posljednji provedeni izračun indeksa razvijenosti čije je rezultate Ministarstvo regionalnog razvoja i fondova Europske unije objavilo u siječnju 2018., pokazuje da vrijednost indeksa razvijenosti za Vukovarsko-srijemsku županiju iznosi 91,992. Drugim riječima, Vukovarsko-srijemska županija nalazi se među ispodprosječno razvijenim hrvatskim županijama. Štoviše, nalazi se na devetnaestom mjestu, odnosno među tri županije s najlošijim vrijednostima ukupnog pokazatelja stupnja društveno-gospodarske razvijenosti. Analiza stanja po pojedinim pokazateljima (prikazana u Tablici 1) otkriva da je Vukovarsko-srijemska županija gotovo u svim kategorijama na začelju.

U odnosu na nacionalni prosjek, najnepovoljnija je situacija po pitanju stope nezaposlenosti, a znatno zaostajanje je primjetno i s obzirom na prosječni dohodak po stanovni$\mathrm{ku}$, zatim prosječne izvorne prihode jedinice područne samouprave, ukupnu demografsku bilancu te obrazovnu strukturu stanovništva.

Ipak, ima i jedan element u kojem je Vukovarsko-srijemskoj županija bolja u odnosu na nacionalni prosjek. Naime, vrijednost indeksa starenja pokazuje da je u Vukovarsko-srijemskoj županiji još uvijek više osoba mlađih od 20 godina nego onih starijih od 59 godina. Takav, relativno povoljan pokazatelj dobne strukture evidentiran je tek u tri 


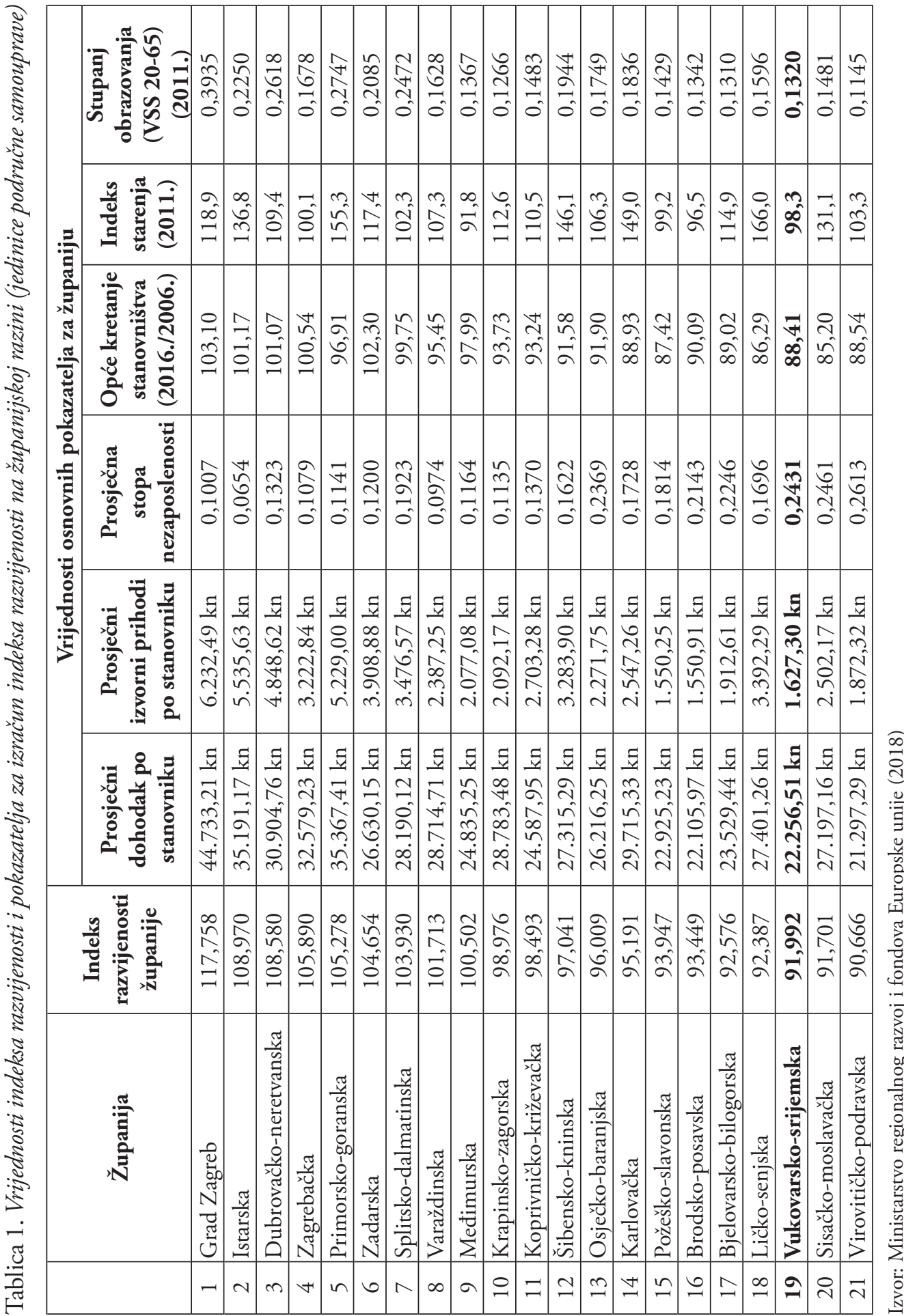


hrvatske županije. Prema tome, Vukovarsko-srijemska županija još uvijek ima određene unutarnje kapacitete za demografsku obnovu.

Međutim, s obzirom na uočene opće demografske trendove, vjerojatno će i ti kapaciteti uskoro izostati. ${ }^{1}$ Kada je riječ o negativnim demografskim trendovima na prostoru Vukovarsko-srijemske županije misli se, dakako, na suočavanje sa značajnim gubitkom stanovništva, pri čemu projekcije pokazuju da će se negativni trendovi nastaviti i u budućnosti. Za razliku, ipak, od nekih drugih slavonskih županija u kojima je pad broja stanovnika bio uočljiv već šezdesetih godina, Vukovarsko-srijemska županija je sve do 1991. bilježila porast broja stanovnika (Akrap, 2018). Na području županije živjelo je tako 1961. 193.224 stanovnika, a 1991. njih 214.658. Međutim poslijeratni popisi pokazuju značajan pad stanovnika pa je tako na području županije 2001. živjelo 186.185, a 2011. 179.521 stanovnika. Prema jednoj projekciji broj stanovnika županije bi uz sadašnje demografske trendove 2051. mogao biti 110.394 (Akrap, 2018). Koliko je iseljavanje stanovnika postalo ozbiljan problem sugerira i činjenica da je prema službenim podacima u razdoblju od 2014. do 2016. u Vukovarsko-srijemsku županiju doselilo 1215 stanovnika, a iselilo njih 6324 , što znači da je broj iseljenih na 100 doseljenih bio 520,5 (Pokos, 2017). Prema demografu Anđelku Akrapu gradovi bi svojom gospodarskom i društvenom infrastrukturom trebali imati ključnu ulogu u zadržavanju stanovništva na prostoru županije. Ostaje dakako pitanje što se treba promijeniti da gradovi počnu ostvarivati pozitivan migracijski saldo čime bi se stvorili uvjeti nadilaženja negativnih demografskih trendova na području županije. U tome kontekstu tema odlaska / ostanka mladih dodatno dobiva na važnosti i nameće se kao jedno od temeljnih razvojnih problema Vukovarsko-srijemske županije.

\section{CILJEVI I METODOLOGIJA ISTRAŽIVANJA}

U ovom radu postavljena su dva istraživačka cilja. Prvi je utvrditi ocjenu kvalitete života mladih u Vukovarsko-srijemskoj županiji, s kojim dimenzijama kvalitete života su zadovoljni, a s kojima nezadovoljni. Drugi je cilj utvrditi postoji li razlika u ocjeni kvalitete života između onih koji bi u budućnosti htjeli živjeti u Vukovarsko-srijemskoj županiji i onih koji bi htjeli živjeti negdje drugdje. U tom kontekstu je postavljena hipoteza da postoji povezanost između ocjene kvalitete života i predmigracijskih očekivanja ispitanika, pri čemu će oni koji više vrednuju kvalitetu života u većoj mjeri željeti u budućnosti nastaviti živjeti na području Vukovarsko-srijemske županije.

\footnotetext{
1 Naime, premda je prethodno spomenuta dobna struktura stanovništva relativno povoljna u odnosu na veći broj drugih županija u Hrvatskoj, trendovi su i po ovom pitanju generalno nepovoljni. Stanovništvo Vukovarsko-srijemske županije pokazuje znakove demografskog starenja, što se vidi iz povećanog indeksa demografskog starenja. Ovaj indeks izračunat na stanovništvu županije 1961. bio je 21,6 da bi 2011. iznosio 100,8 (Pejaković, 2016). Međutim, važno je napomenuti da se taj indeks računa prema drugačijoj metodologiji u odnosu na podatak iznesen u Tablici 1 . U jednom slučaju indeks se računa na temelju podataka o populaciji starijih od 65 i mlađih od 14 godina, a u drugom na temelju podataka o populaciji starijih od 60 i mlađih od 19 godina.
} 
Ciljana skupina su bili učenici trećih i četvrtih razreda srednjih škola na području Vukovarsko-srijemske županije.

Istraživanje je provedeno u dvije faze, na način da se prvo provelo kvalitativno istraživanje putem polustrukturiranih intervjua u kojima je sudjelovalo dvanaest ispitanika. Istraživanje je provedeno u razdoblju od 7. prosinca 2018. do 27. siječnja 2019. Putem intervju nastojalo se saznati kako sami ispitanici definiraju koncept kvalitete života, koje aspekte kvalitete života drže dobrima u Vukovarsko-srijemskoj županiji, a koje lošima, kakav je njihov odnos prema pojedinim vrijednostima te kakvi su im planovi za budućnost. Dobiveni rezultati korišteni su u pripremi druge faze istraživanja, dakle, u formiranju anketnog upitnika. Za svrhu anketnog istraživanja priređen je upitnik $s$ ukupno 42 pitanja čije korištenje je odobrilo etičko povjerenstvo Instituta društvenih znanosti Ivo Pilar. Prije anketiranja učenici su upoznati sa sadržajem i svrhom istraživanja, zajamčena im je povjerljivost prikupljenih podataka te je uz njihov usmeni pristanak tražen i pismeni pristanak njihovih roditelja / skrbnika. Anketiranje je provedeno u svih petnaest srednjih škola koje se nalaze na području županije i to na probabilističkom stratificiranom uzorku. Uočena manja odstupanja uzorka od populacijskih vrijednosti po kriterijima mjesta školovanja, školskog programa (gimnazijski ili strukovni) i razreda korigirani su korištenjem pondera te je na taj način osigurana reprezentativnost uzorka za navedene kriterije. Provedbu anketnog istraživanja organizirali su sami istraživači, a trajalo je od 21. veljače 2019. do 21. ožujka 2019., pri čemu su prikupljena 744 ispravno ispunjena anketna upitnika. U Tablici 2 prikazana su izabrana obilježja uzorka. $\mathrm{U}$ ovom istraživanju kvaliteta života operacionalizirana je putem osam dimenzija. $\mathrm{Pr}$ vih sedam preuzeto je, uz određene manje izmjene, iz prethodnih istraživanja (Slavuj, 2012a; Eurofound, 2014). To su dimenzije stanovanja, prirodnog okoliša, sigurnosti, kvalitete usluga i sadržaja, prometa i infrastrukture, socijalnih veza u susjedstvu, te povjerenja u institucije. Posljednja dimenzija kojom se istraživala kvaliteta života nazvana percepcija mogućnosti zapošljavanja formirana je na temelju rezultata kvalitativnog istraživanja. Zapaženo je, naime, da su sudionici istraživanja u velikoj mjeri povezivali pojam kvalitete života $s$ mogućnosti zapošljavanja te mogućnošću pronalaska dobro plaćenog posla. Dakako, treba reći da se rad i zapošljavanje i inače često koriste pri operacionalizaciji koncepta kvalitete života (Eurofound, 2014).

Međutim, ovdje nisu korištena uobičajena pitanja iz sličnih istraživanja, kojima se detaljnije prati dimenzija rada te uvjeti rada, već se pitanja nastojalo prilagoditi specifičnoj populaciji ove županije. Navedene dimenzije kvalitete života operacionalizirane su različitim brojem čestica koje su nakon utvrđivanja jednofaktorske strukture i zadovoljavajućeg Cronbachovog alpha spajane u jednu varijablu. Pritom se problematičnom pokazala dimenzija prometa i infrastrukture koja nije pokazivala očekivanu jednofaktorsku strukturu pa je stoga podijeljena u dvije dimenzije, prometnu povezanost i infrastrukturu².

2 Dimenzije su mjerene putem sljedećih čestica: 1. Zadovoljstvo sadržajima i uslugama (trgovine za svakodnevnu opskrbu, trgovine s odjećom i obućom, broj i kvaliteta kafića, sportski objekti, obrazovne institucije, 
Cronbachov alpha za navedene dimenzije kretao se u rasponu od 0,87 (zadovoljstvo susjedstvom) do 0,66 (zadovoljstvo infrastrukturom) što upućuje na prihvatljivu pouzdanost korištenih jednofaktorskih struktura.

Tablica 2. Osnovna obiljě̌ja ispitanika obuhvaćenih istraživanjem nakon provedene korekcije uzorka

\begin{tabular}{|l|l|c|}
\hline \multirow{2}{*}{ Spol } & Muški & $49,1 \%$ \\
\cline { 2 - 3 } & Ženski & $50,9 \%$ \\
\hline \multirow{4}{*}{ Veličina mjesto stanovanja } & $<4.001$ stanovnika & $47,0 \%$ \\
\cline { 2 - 3 } & $4.001-15.000$ stanovnika & $19,4 \%$ \\
\cline { 2 - 3 } & $>15.000$ stanovnika & $33,6 \%$ \\
\hline \multirow{4}{*}{ Mjesto školovanja } & Vinkovci & $60,2 \%$ \\
\cline { 2 - 3 } & Vukovar & $21,1 \%$ \\
\cline { 2 - 3 } & Županja & $17,1 \%$ \\
\cline { 2 - 3 } & Ilok & $1,5 \%$ \\
\hline \multirow{2}{*}{ Obrazovni program } & Gimnazija & $27,5 \%$ \\
\cline { 2 - 3 } & Strukovna škola & $72,5 \%$ \\
\hline \multirow{2}{*}{ Razred } & Treći & $57,3 \%$ \\
\cline { 2 - 3 } $\begin{array}{l}\text { Procjena životnog standarda kućanstva u } \\
\text { odnosu na nacionalni prosjek }\end{array}$ & Četvrti & $42,7 \%$ \\
\cline { 2 - 3 } & Ispod prosjeka & $11,1 \%$ \\
\cline { 2 - 3 } & Prosječan & $58,3 \%$ \\
\hline
\end{tabular}

U radu će se također koristiti i rezultati dobiveni na sljedećim varijablama: procjena zadovoljstva vlastitim životom, očekivanje kako će se za pet godina živjeti u sadašnjem mjestu stanovanja, mjesto u kojem bi se željelo živjeti po završetku školovanja te mjesto stanovanja s obzirom na veličinu naselja i područje unutar županije.

zdravstvene institucije, dostupnost ljekarni), 2. Kvaliteta stanovanja (kvaliteta i opremljenost objekta, veličina objekta, izdaci za stan ili kuću), 3. Prirodni okoliš (odlaganje krutog otpada, broj zelenih površina, kvaliteta zraka, održavanje čistoće i urednosti zelenih površina) 4. Kvaliteta susjedstva (druženje sa susjedima, spremnost susjeda na pomoć, svakodnevno ponašanje susjeda), 5. Sigurnost susjedstva (osjećaj sigurnosti noću kod kuće, osjećaj sigurnosti noću na ulicama, osjećaj sigurnosti u sredstvima javnog prijevoza), 6. Prometna povezanost (povezanost unutar grada školovanja, povezanost naselja u županiji, povezanost $s$ većim hrvatskim gradovima izvan županije), 7. Infrastruktura (dostupnost parkirališnih mjesta, kvaliteta prometnica, kvaliteta internetskih veza, opskrba pitkom vodom, opskrba električnom energijom), 8. Zadovoljstvo mogućnošću zapošljavanja (mogućnost pronalaska posla, dostupnost dobro plaćenih radnih mjesta, transparentnost zapošljavanja, dostupnost raznolikih radnih mjesta, dostupnost radnih mjesta $s$ mogućnošću napretka), 9. Povjerenje u institucije (čestice prikazane u Slici 2). 


\section{REZULTATI ISTRAŽIVANJA I RASPRAVA}

Potrebno je za početak postaviti pitanje kakvi su općenito mladi u Vukovarsko-srijemskoj županiji. Dakle iz dobivenih rezultata istraživanja može se primijetiti da su dominantno zadovoljni svojim životom. Naime njih čak $71,5 \%$ odgovorilo je da je uglavnom ili izrazito zadovoljno svojim životom dok ih je 9,7\% odgovorilo da je izrazito ili uglavnom nezadovoljno svojim životom. Potrebno je stoga razmotriti kako ocjenjuju pojedine dimenzije kvalitete života te postoji li povezanost ukupne ocjene kvalitete života i očekivanja od budućnosti.

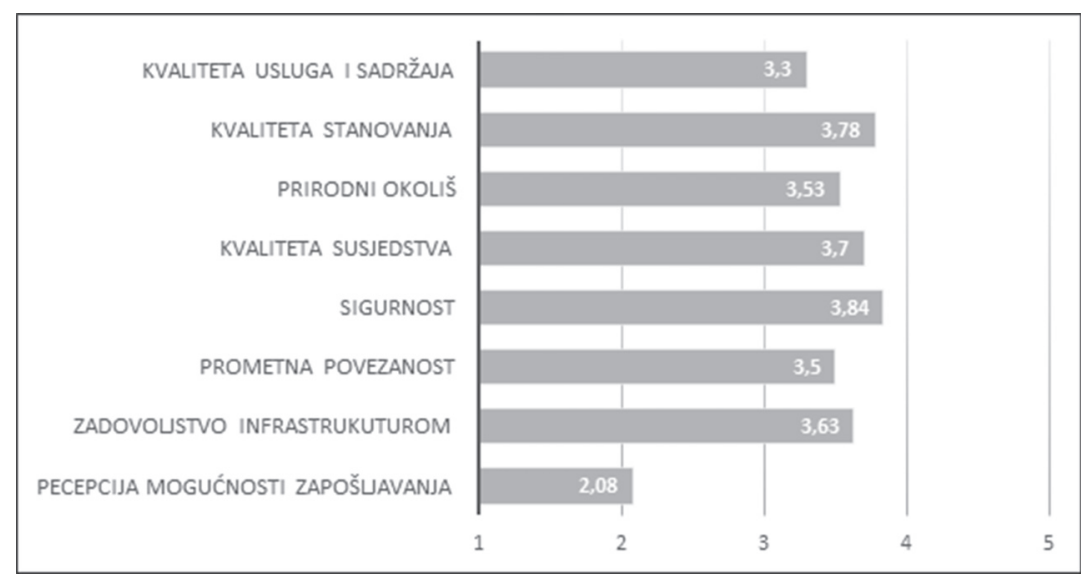

Slika 1. Zadovoljstvo pojedinim dimenzijama kvalitete života*

*Zadovoljstvo je mjereno na skali: izrazito nezadovoljan (1), uglavnom nezadovoljan (2), ni zadovoljan ni nezadovoljan (3), uglavnom zadovoljan (4) i izrazito zadovoljan (5).

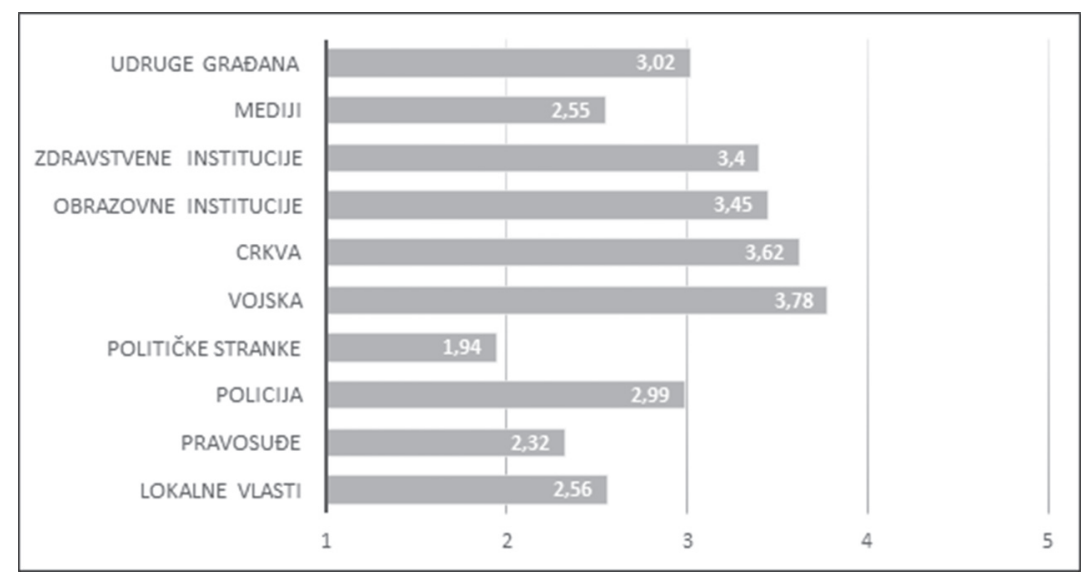

Slika 2. Povjerenje u institucije*

*Povjerenje je mjereno na skali: nemam ni malo povjerenja (1), uglavnom nemam povjerenja (2), niti imam niti nemam povjerenja (3), uglavnom ima povjerenja (4) i u potpunosti imam povjerenja (5). 
Kada su u pitanju sve dimenzije kvalitete života korištene u ovom radu, one načelno mogu grupirati u tri skupine - opremljenost neposredne životne okoline, primarno društveno okružje te strukturno društveno okružje. ${ }^{3}$ Pojam opremljenosti neposredne životne okoline koristi se da bi označio u kojoj se mjeri na nekom prostoru mogu zadovoljiti određene životne potrebe te olakšati svakodnevni život stanovnika (Svirčić Gotovac, 2006; Klempić Bogadi i sur., 2015).

On se stoga uobičajeno odnosi na zadovoljavajuću opremljenost prostora uslugama, sadržajima, kvalitetnu prometnu povezanost i infrastrukturu, ali će se u ovom radu odnositi i na kvalitetu stanovanja te kvalitetu prirodnog okoliša. Opremljenost neposredne životne okoline, dakle, obuhvaća svojevrsnu materijalnu i uslužnu bazu svakodnevnog života te se tiče sposobnosti društvenih grupa da prilagode svojim organizacijskim potrebama, bilo izmjenama bilo očuvanjem, materijalnu okolinu u kojoj djeluju. Drugu skupinu čine dimenzije sigurnost i socijalne veze u susjedstvu, a nazvana je primarno društveno okružje. Tijekom rasprava o razvoju gradova u modernosti osobita pažnja se posvećivala predodžbama velikih gradova u odnosu na seoske sredine. U popularnim prikazima gradovi su nerijetko bili prikazivani kao mjesta kriminala, nesigurnosti, socijalne dezintegracije i raspada tradicionalnih zajednica, dakle implicirala se kriza onoga što se u ovom radu naziva primarno društveno okružje (Gottdiener i Hutchinson, 2011). Napokon treću skupinu čine dimenzije percepcije mogućnosti zapošljavanja i povjerenja u institucije, a nazvana je strukturno društveno okružje.

Iz Slike 1 može se zaključiti da su mladi najzadovoljniji sigurnošću, stanovanjem te socijalnim vezama u susjedstvu. To pokazuje da su mladi većinski zadovoljni dimenzijama uvrštenim u primarno društveno okružje. Aspekt sigurnosti je, kako su pokazali rezultati istraživanja iz 2006., na vrlo visokom nivou u Republici Hrvatskoj (Japec i Šućur, 2007). Naime, pokazalo se da su s ovim aspektom kvalitete života građani Hrvatske zadovoljniji nego građani Europske unije. U Hrvatskoj je tada bilo samo 12\% ispitanika koji su se noću osjećali nesigurno u svom susjedstvu, dok je taj broj u 25 država koje su u Europsku uniju ušle do 2004. bio 23\%. Usprkos tome što su različite posljedice rata ostavile više traga u Vukovarsko-srijemskoj županiji nego u nekim drugim dijelovima Hrvatske pokazuje se da mladi visoko ocjenjuju sigurnost u svojim naseljima.

Uz sigurnost, i kvaliteta susjedstva je relativno dobro ocjenjena. Tako je 64,9\% mladih uglavnom ili vrlo zadovoljno spremnošću susjeda na pomoć u slučaju potrebe, njih 66,2\% zadovoljno je svakodnevnim ponašanjem svojih susjeda, dok ih je 55,9\% zadovoljno druženjem sa susjedima. ${ }^{4}$ Ipak, jasno je da ovim instrumentom, mjerenim s tri čestice, nije moguće donijeti neke dalekosežne zaključke o socijalnoj koheziji na lokalnoj razini (Miletić i sur., 2016).

\footnotetext{
3 Za nešto drugačije grupiranje dimenzija kvalitete života pri prezentaciji rezultata vidi istraživanje Lane Slavuj u kojem su varijable podijeljene na aspekte socijalnog okoliša i aspekte prirodnog okoliša (Slavuj, 2012c).

$4 \mathrm{U}$ daljnjem tekstu će se u prikazu zadovoljstva ispitanika koristiti zbrojeni odgovori ispitanika na opcijama uglavnom zadovoljan i izrazito zadovoljan, dok će se za prikaz njihova nezadovoljstvu navoditi odgovori onih koji su izrazito ili uglavnom nezadovoljni.
} 
Kada su u pitanju dimenzije svrstane u opremljenost neposredne životne okoline, stavovi mladih teže prema blagom zadovoljstvu. Osobito je zadovoljstvo prisutno na dimenziji stanovanja. Premda su rezultati istraživanja iz 2004. ukazivali na određene probleme u kvaliteti stanovanja u Republici Hrvatskoj, osobito u manjim naseljima, mladi iz Vukovarsko-srijemske županije danas su njome uglavnom zadovoljni (Svirčić Gotovac, 2006). Dominantno se zadovoljstvo iskazivalo veličinom (kojom je zadovoljno 84,2\% ispitanih) i opremljenošću objekta u kojem stanuju (82,1\% zadovoljnih). Rezultati istraživanja provedenog 2012. na populaciji mladih u Republici Hrvatskoj također su ukazali na zadovoljavajuću situaciju po pitanju stanovanja u usporedbi s nekim drugim važnim životnim aspektima. Premda je u tom istraživanju kvaliteta stanovanja mjerena na drugačiji način (brojem soba u stambenom objektu), zaključeno je da „stambena situacija obitelji mladih bolja od primanja kojima ista ta kućanstva raspolažu" (Ilišin i sur., 2013:27). Važnost nekretnina, odnosno tradicija ulaganja u nekretnine građana Hrvatske, navedena je kao mogući razlog zadovoljavajuće situacije u pogledu stambenih prilika.

Nakon toga slijede dimenzije zadovoljstva infrastrukturom, prometne povezanosti i prirodnog okoliša kod kojih odgovori također u nešto većoj mjeri tendiraju prema zadovoljstvu nego nezadovoljstvu. Kada su u pitanju problemi vezani uz promet oni ne zaobilaze ni stanovnike najrazvijenijih svjetskih država. Obično se kao najistaknutiji problemi ističu nedostatak novca, slabo planiranje, odsutnost prometne mreže ili slaba kvaliteta postojeće infrastrukture. U slučaju Hrvatske dodatnu teškoću u prometnom sustavu uzrokovao je značajan porast broja cestovnih vozila (Rogić i sur., 2008). Važno je stoga promotriti kako mladi u Vukovarsko-srijemskoj županiji gledaju na pitanje prometne povezanosti, kao i pojedinih infrastrukturnih pitanja vezanih za promet. Općenito se može reći da je najveći broj mladih, njih 61,9\%, zadovoljan prometnom povezanošću unutar grada u kojem stanuje ili se školuje. Nešto manje ih je zadovoljno povezanošću između naselja u županiji $(55 \%)$ i povezanošću s većim hrvatskim gradovima (54,3\%). Zanimljivo je da su u cjelini mladi zadovoljniji infrastrukturom nego prometnom povezanošću, no da je u domeni infrastrukture upravo jedan prometni aspekt najlošije ocijenjen. Radi se o kvaliteti prometnica s kojom 31,2\% mladih nije zadovoljno. Mladi su podijeljeni i oko kvalitete internetskih veza (33,6\% nezadovoljnih i 44,4\% zadovoljnih), nešto su zadovoljniji dostupnošću parkirališnih mjesta $(55,9 \%)$, a najzadovoljniji opskrbom pitkom vodom $(82,4)$ i opskrbom električnom energijom $(86,9 \%)$.

Kvaliteta prirodnog okoliša također se ubraja u važne dimenzije koje utječu na kvalitetu života budući da može utjecati na zdravlje stanovnika, omogućiti kvalitetnije provođenje slobodnog vremena te, općenito, učiniti okružje estetski privlačnijim. Mladi u Vukovarsko-srijemskoj županiji su pri ocjeni kvalitete prirodnog okoliša u najvećem broju zadovoljni brojem zelenih površina u mjestu stanovanja $(69,9 \%)$ dok ih je najmanji broj zadovoljan načinom na koji se rješava pitanje odlaganja krutog otpada (37,7\%).

Od dimenzija podvedenih pod naziv opremljenost neposredne životne okoline najmanje su zadovoljstva ispitanici pokazali na onoj kvalitete usluga i sadržaja pri čemu je 54\% mladih uglavnom ili izrazito nezadovoljno kvalitetom trgovina s odjećom i obućom. 
Može se na kraju primijetiti da se varijable koje pokazuju nezadovoljstvo mladih koncentriraju u dvije dimenzije, koje su nazvane strukturno društveno okružje, a koje uključuju percepciju mogućnosti zapošljavanja te povjerenje u pojedine institucije. Kada je u pitanju percepcija mogućnosti zapošljavanja mladi su većinom nezadovoljni sa svih pet čestica putem kojih se ova dimenzija operacionalizirala, a koje su se ticale kako dostupnosti radnih mjesta tako i transparentnosti zapošljavanja. Ovo se čini osobito zabrinjavajućim ako se uzme u obzir da je jedna od mjera koja se preporučila kao važna u zaustavljanju negativnih demografskih i razvojnih procesa navodila i zadržavanje i zapošljavanje mladog stanovništva (Pejaković, 2016).

Paralelno s niskom ocjenom mogućnosti zapošljavanja mladi pokazuju i dosta slabo povjerenje u neke od važnih institucija. Smatra se da institucije u modernim društvima predstavljaju skupove pravila koja bi trebala omogućiti lakše snalaženje u kompleksnom okružju te tako stabilizirati demokratski poredak, učiniti neke društvene situacije predvidivijim te, shodno tome, omogućiti kvalitetan život građana (Gvozdanović, 2014). Problematično je međutim da prema rezultatima istraživanja u Hrvatskoj kontinuirano postoji relativno nisko povjerenje u važne društvene institucije: političke institucije, pravosude i medije. Povjerenje u te institucije se komparativno pokazivalo i 2007. i 2012. znatno nižim nego u zemljama Europske unije (Eurofound, 2014). Istovremeno, istraživanja su pokazivala da građani Hrvatske nešto više povjerenja imaju u vojsku i crkvu. Primjerice rezultati istraživanja Pilarov Barometar (2015), u kojem su ispitanici na skalama od 1 do 10 ocjenjivali povjerenje u različite institucije, pokazali su da su građani Hrvatske najviše povjerenja imali u vojsku $(M=5,6)$, a potom u crkvu $(M=5,2)$. Još neke institucije iz navedenog istraživanja, prema ukazanom povjerenju građana bile su policija $(M=4,5)$, pravosuđe $(M=3,2)$, političke stranke $(M=2,0)$. Kada se pogledaju rezultati iz Tablice 2 lako je uočiti da rezultati povjerenja u institucije mladih iz Vukovarsko-srijemske županije ovog istraživanja ne odstupaju značajno od navedenog poretka.

Tako i oni najviše povjerenja iskazuju prema vojsci i crkvi, nakon čega slijede zdravstvene i obrazovne institucije, a potom udruge građana i policija. Prema aritmetičkim sredina povjerenje u udruge građana i policiju kreće se oko vrijednosti tri koja je glasila „Niti imam niti nemam povjerenje“. Institucije za koje se pokazalo da uživaju nisko povjerenje ispitanika su lokalne vlasti, mediji, pravosude i na kraju političke stranke. Dakle, mladi, kada je u pitanju povjerenje u ključne institucije, pokazuju vrlo slične rezultate onima drugih istraživanjima koja su se provodila u Hrvatskoj, pri čemu se redovito ponavljalo da političke institucije, osobito političke stranke, imaju najniže povjerenje građana (Gvozdanović, 2014).

Ipak, s obzirom na brojne posljedice rata, slabu prilagodbu postindustrijskom dobu te, kako se pokazalo, slabu percepciju mogućnosti zapošljavanja, nepovjerenje iskazano prema pravosuđu i lokalnim vlastima te političkim strankama, kao važnim institucijama društveno-političkog upravljanja, na području Vukovarsko-srijemske županije može imati dodatno teške posljedice. Naime, u procesu poslijeratne obnove građenje se socijalnog kapitala, kroz jačanje povjerenja u ljude, institucije i okružje, isticalo kao važan uvjet društvenog i gospodarskog razvoja ovog područja (Šundalić i Barković, 2008). 
Kada su u pitanju razlike koje eventualno postoje među mladima iz Vukovarsko-srijemske županije u pogledu zadovoljstva pojedinim dimenzijama kvalitete života, ispitanici su podijeljeni prema dva kriterija: gradu u kojem se školuju i veličini naselja u kojem žive. Prema prvom kriteriju, ispitanici se dijele na tri grupe, one koji pohađaju srednju školu u Vinkovcima, one koji je pohađaju u Vukovaru te one koji je pohađaju u Županji. $S$ obzirom na mali broj ispitanika učenici koji pohađaju školu u Iloku nisu uzeti u analizu. Ovaj kriterij čini se opravdanim, budući da je utvrđeno da najveći broj učenika koji pohađaju nastavu u tim gradovima dolazi iz samih gradova ili okolnih naselja koja gravitiraju istima. ${ }^{5}$ Stoga se na osnovu ovog kriterija može govoriti o tri područja: širem vukovarskom području, širem vinkovačkom području te širem županjskom području. Kada je u pitanju veličina naselja ispitanici su podijeljeni u tri skupine. U prvoj skupini su učenici koji dolaze iz naselja većih od 15000 stanovnika, što su u Vukovarsko-srijemskoj županiji samo gradovi Vinkovci i Vukovar. U drugoj skupni su učenici koji dolaze iz naselja koja imaju između 4000 i 15000 stanovnika. Tu skupinu čine preostala tri naselja koja imaju status grada, Županja, Ilok i Otok te naselja Borovo i Ivankovo. Napokon, u trećoj skupini su učenici koji dolaze iz naselja manjih od 4000 stanovnika, tj. svih ostalih naselja u županiji.

Iz rezultata prikazanih u Tablici 3 vidljivo je da je kvaliteta života u velikom broju dimenzija homogeno raspoređena, kada je u pitanju podjela na vinkovačko, vukovarsko i županjsko područje. Razlike, pak, postoje na dimenziji sigurnosti, prometne povezanost te pojedinim dimenzijama povjerenja u institucije. Kada je u pitanju prometna povezanost, učenici koji pohađaju nastavu u Županji pokazuju veći stupanj zadovoljstva od učenika iz Vukovara i Vinkovaca. Rezultat bi mogao biti posljedica dobrog prometnog položaja Županje koja je u neposrednoj blizini autoceste što joj olakšava pristup drugim gradovima. Za interpretaciju manjeg zadovoljstva mladih koji pohađaju nastavu u Vinkovcima bilo bi potrebno provesti daljnje istraživanje ili imati bolji uvid u statističke podatke koji se tiču sigurnosti u županiji.

Kada je u pitanju povjerenje $\mathrm{u}$ institucije razlike se pojavljuju u slučaju povjerenja u vojsku, crkvu, obrazovne i zdravstvene institucije. Može se uočiti da učenici iz Vukovara u svim slučajevima pokazuju nešto manje povjerenje u institucije u odnosu na učenike iz ostala dva grada.

Nešto više razlika u ocjeni kvalitete života pojavljuje se pri podjeli ispitanika po kriteriju veličine naselja u kojem stanuju. Pokazuje se pritom da se razlike u povjerenju u institucije dosljedno ponavljaju. Naime, mladi iz većih županijskih gradova imaju nešto manje povjerenja u policiju, vojsku, crkvu i obrazovne institucije u odnosu na mlade iz najmanjih naselja, a kada je riječ o crkvi i obrazovnim institucijama i u odnosu na mlade koji žive u naseljima od 4000 do 15000 stanovnika. Prema ovim institucijama osobito

5 U vinkovačkim školama tako veći broj učenika dolazi iz sljedećih mjesta: Ivankovo, Privlaka, Komletinci, Nijemci, Jarmina i grada Otoka. U Vukovaru je među ispitanicima zabilježen određen broj učenika iz Negoslavaca, Bogdanovaca i Borova, dok je u Županji veći broj učenika dolazio iz Bošnjaka i Drenovaca. 
važnim za održavanje poretka, koje pritom imaju i relativno jasnu hijerarhijsku podjelu uloga, očito mladi iz većih gradova zadržavaju nešto veću razinu kritičkog propitivanja.

Tablica 3. Razlike u ocjeni pojedinih dimenzija kvalitete života s obzirom na teritorijalne kriterije

\begin{tabular}{|c|c|c|c|}
\hline \multicolumn{2}{|c|}{ Dimenzije kvalitete života } & 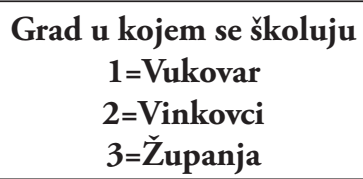 & $\begin{array}{c}\text { Veličina naselja } \\
1=\text { više od } 15.000 \\
2=\text { od } 4.000 \text { do } 15.000 \\
3=\text { manje od } 4.000\end{array}$ \\
\hline \multicolumn{2}{|c|}{ Kvaliteta usluga i sadržaja } & - & $1(3,40)>3(3,22)$ \\
\hline \multicolumn{2}{|c|}{ Kvaliteta stanovanja } & - & - \\
\hline \multicolumn{2}{|c|}{ Prirodni okoliš } & - & $3(3,65)>1(3,38)$ \\
\hline \multicolumn{2}{|c|}{ Kvaliteta susjedstva } & - & $2(3,81), 3(3,81)>1(3,45)$ \\
\hline \multicolumn{2}{|c|}{ Sigurnost } & $1(4), 3(4,01)>2(3,74)$ & - \\
\hline \multicolumn{2}{|c|}{ Prometna povezanost } & $3(3,81)>1(3,48), 2(3,49)$ & - \\
\hline \multicolumn{2}{|c|}{ Zadovoljstvo infrastrukturom } & - & - \\
\hline \multicolumn{2}{|c|}{ Mogućnost zapošljavanja } & - & $3(2,15)>2(1,92)$ \\
\hline \multirow{10}{*}{ 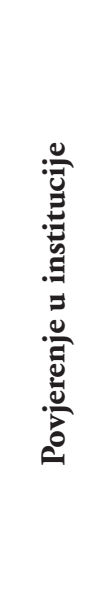 } & Lokalne vlasti & - & - \\
\hline & Pravosude & - & - \\
\hline & Policija & - & $3(3,14)>1(2,80)$ \\
\hline & Političke stranke & - & - \\
\hline & Vojska & $2(3,83), 3(3,99)>1(3,44)$ & $3(3,86)>1(3,6)$ \\
\hline & Crkva & $2(3,7)>1(3,33)$ & $2(3,70), 3(3,76)>1(3,35)$ \\
\hline & Obrazovne institucije & $3(3,58)>1(3,29)$ & $2(3,53), 3(3,55)>1(3,25)$ \\
\hline & $\begin{array}{l}\text { Zdravstvene } \\
\text { institucije }\end{array}$ & $3(3,69)>1(3,33), 2(3,34)$ & - \\
\hline & Mediji & - & - \\
\hline & Udruge građana & - & - \\
\hline
\end{tabular}

Osim toga, na tri dimenzije kvalitete života dobivene su statistički značajne razlike koje nisu iznenađujuće. Tako mladi iz većih gradova nešto više vrednuju kvalitetu sadržaja i usluga u odnosu na mlade iz najmanjih naselja, dok istovremeno ispitanici iz najmanjih naselja nešto kvalitetnijim ocjenjuju prirodni okoliš. Usprkos tome što se ne radi o velikim gradovima Vinkovci i Vukovar nude sigurno nešto više sadržaja pa su učenici iz tih gradova bili zadovoljniji sportskim objektima i dostupnošću ljekarni nego učenici iz manjih seoskih sredina. No, učenici iz manjih seoskih sredina su bili zadovoljniji brojem zelenih površina ali i održavanjem čistoće i urednosti tih površina u odnosu na učenike 
iz većih gradova. Kvalitetu susjedstva su također učenici iz najvećih županijskih naselja ocijenili nešto nižom od ispitanika iz obje skupine manjih naselja.

Rezultat koji je, ipak, najteže kvalitetno interpretirati je da učenici iz naselja između 4 000 i 15000 stanovnika najlošije percipiraju mogućnosti zapošljavanja, a ta razlika je statistički značajna u odnosu na učenike iz najmanjih naselja. Interpretiranje tog podatka nije moguće bez dubljeg uvida u stanje u kojem se nalaze ova naselja, ali upućuje ba osobito teško stanje ovih naselja u kojima postoje urbane aspiracije, ali su zbog različitih razloga otežane mogućnosti upravljanja i razvoja.

U istraživanju koje je 2009. provedeno na području Vukovarsko-srijemske županije ispitanike se pitalo koliko su zadovoljni ili nezadovoljni rješavanjem pojedinih pitanja i problema u njihovom mjestu (Mišetić i sur., 2012). Tada je među stanovnicima Vukovarsko-srijemske županije nešto istaknutije bilo zadovoljstvo sa sljedećim aspektima: zaštitom i sigurnošću stanovnika (48,1\% zadovoljnih), održavanjem mjesta / grada (46,4\% zadovoljnih) i komunalnom opremom (43\% zadvoljnih). Zanimljivo je međutim da je najmanje zadovoljstva tada iskazano prema „Brizi o mladima i njihovoj budućnosti“. Naime samo 15\% ispitanih je bilo zadovoljno rješavanjem tog pitanja, dok je njih čak $61,1 \%$ bilo nezadovoljno. Važno je stoga razmotriti kako desetak godina nakon tog istraživanja sami mladi gledaju na svoju budućnost, odnosno gdje bi nakon završetka školovanja željeli nastaviti živjeti. Rezultati su prikazani u Tablici 4.

Prema dobivenim rezultatima samo 35,8\% mladih htjelo bi živjeti na području županije, bilo u sadašnjem mjestu stanovanja ili u nekom drugom mjestu, 32,1\% njih voljelo bi živjeti na području Republike Hrvatske, ali ne u Vukovarsko-srijemskoj županiji, a njih 32,1\% voljelo bi živjeti negdje izvan Hrvatske.

Ti podaci su svakako zabrinjavajući sa stajališta Vukovarsko-srijemske županije. Dakle, mladi, iako su dominantno zadovoljni svojim životom, njih gotovo dvije trećine željelo bi nakon završetka školovanja živjeti izvan područja županije. Međutim, podaci nisu toliko iznenađujući ako ih se usporedi s rezultatima sličnih istraživanja koja se, osobito posljednjih godina, provode na području Republike Hrvatske.

\section{Tablica 4. Želje mladih vezane za mjesto stanovanja nakon završetka školovanja}

\begin{tabular}{|l|c|}
\hline \multicolumn{2}{|c|}{ Gdje biste željeli provesti glavninu svog života nakon završetka obrazovanja? } \\
\hline U sadašnjem mjestu stanovanja & $27,6 \%$ \\
\hline U drugom mjesto na području Vukovarsko-srijemske županije & $8,2 \%$ \\
\hline $\begin{array}{l}\text { U drugom mjestu u Republici Hrvatskoj ali ne na području Vukovarsko- } \\
\text { srijemske županije }\end{array}$ & $32,1 \%$ \\
\hline U drugoj državi u Europskoj uniji & $18,9 \%$ \\
\hline U drugoj europskoj državi izvan Europske unije & $2,5 \%$ \\
\hline $\begin{array}{l}\text { U drugoj izvaneuropskoj državi (npr. SAD, Kanada, Australija, Novi } \\
\text { Zeland i sl.) }\end{array}$ & $10,7 \%$ \\
\hline
\end{tabular}


Nešto starije istraživanje, provedeno 1999., a koje vrijedi spomenuti jer su u njemu sudjelovali maturanti s područja posebne državne skrbi, među koje su spadali i učenici iz Iloka i Vukovara, pokazalo je da bi se 50,2\% anketiranih učenika preselilo u neku drugu državu zbog posla ili studija ukoliko bi im se ukazala prilika (Raboteg-Šarić i Rogić, 2002). Njih 40,4\% nije moglo procijeniti, dok ih je samo 9,4\% bilo sklono opciji ostanka. Rezultati istraživanja provedenog 2012. na populaciji mladih iz cijele Republike Hrvatske su, ipak, davali nešto drugačiju sliku. Tada želja da se iseli iz Republike Hrvatske uopće nije bila prisutna kod 38,6\% mladih, a kod 31,6\% ta želja nije bila snažna. Jaku ili donekle snažnu želju za iseljenjem tada je iskazivalo $26,8 \%$ ispitanih (Ilišin i sur., 2013).

Rezultate prezentirane u ovom radu zanimljivo je i usporediti $s$ rezultatima istraživanja provedenog 2014. u kojem su sudjelovali maturanti iz četiri najveća hrvatska grada: Zagreba, Splita, Rijeke i Osijeka (Lajić i sur., 2018). Tada je na pitanje „Gdje želiš živjeti“ $35,3 \%$ ispitanih odgovorilo u sadašnjem mjestu stanovanja, 10,6\% u drugom mjestu, ali u Hrvatskoj, dok ih je 38,6\% željelo živjeti izvan Hrvatske, bilo u zemljama Europske unije, bilo u nekim drugim izvaneuropskim državama. Ispitanicima je bila ponuđena i opcija $\mathrm{Ne}$ znam za koju se odlučilo njih $15,5 \%$. Premda su pitanja u ovim istraživanjima postavljena nešto drugačije, kao što su to i opcije koje su ispitanicima bile ponuđene u odgovorima, autori drže da rezultati sugeriraju kako je mladima iz Vukovarsko-srijemske županije u većoj mjeri nego njihovim vršnjacima iz najvećih hrvatskih gradova prihvatljiva opcija migriranja u neko drugo mjesto u Hrvatskoj, dok je kod mladih iz najvećih hrvatskih gradova u većoj mjeri prisutna želja za migriranjem izvan Republike Hrvatske. To je osobito uočljivo pogledaju li se rezultati učenika iz Rijeke, Osijeka i Splita. Iz Rijeke je, naime, 42,6\% mladih odgovorilo da bi željelo živjeti u inozemstvu, iz Osijeka njih 40,6\%, a iz Splita njih 38,5\%. Kako je već spomenuto, u inozemstvu bi voljelo živjeti 32,1\% mladih iz Vukovarko-srijemske županije. Ovi podaci mogu se povezati sa službenim podacima Državnog zavoda za statistiku Republike Hrvatske prema kojima Vukovarsko-srijemska županija kontinuirano ima negativan migracijski saldo u odnosu na druge hrvatske županije, pri čemu je veći broj ljudi odlazio u druge hrvatske županije nego u inozemstvo (Živić i sur., 2017). U razdoblju od 2011. do 2014. iz Vukovarsko-srijemske županije se, prema službenim podacima, iselilo 10556 osoba, od kojih se njih 6672 ili 63,2\% iselilo u druge hrvatske županije, a njih 3887 ili 36,8\% u inozemstvo.

Kako bi se provjerila teza o povezanosti kvalitete života s migracijskim aspiracijama mladih analiziran je odnos između toga gdje bi mladi željeli živjeti nakon završetka školovanja te njihove procjene kvalitete života na području Vukovarsko-srijemske županije. Ispitanici su pritom podijeljeni u samo dvije skupine, one koji bi željeli glavninu života provesti na području Vukovarsko-srijemske županije i one koji bi željeli nakon školovanja živjeti negdje drugdje. Rezultati su prikazani u Tablici 5 iz koje je vidljivo da je statistički značajna razlika zabilježena na gotovo svim dimenzijama kvalitete života. Dakle, razlika je zabilježena na dimenzijama primarnog društvenog okružja, pri čemu su učenici koji bi željeli živjeti na području županije nešto višom ocijenili i kvalitetu 
susjedstva i sigurnost u odnosu na učenike koji bi u budućnosti htjeli živjeti izvan Vukovarsko-srijemske županije. U pogledu opremljenosti neposredne životne okoline razlika nije zabilježena samo u slučaju zadovoljstva infrastrukturom. Međutim učenici koji bi željeli živjeti na području županije u odnosu na one koji bi živjeli radije negdje drugdje više su vrednovali dimenzije stanovanja, kvalitete usluga i sadržaja, prirodni okoliš i prometnu povezanost.

Tablica 5. Povezanost procjene kvalitete života i želje da se nakon školovanja živi na prostoru Vukovarsko-srijemske županije ili negdje izvan nje

\begin{tabular}{|c|c|c|}
\hline \multicolumn{2}{|r|}{ Dimenzije kvalitete života } & $\begin{array}{c}\text { Gdje bi ste željeli nastaviti živjeti nakon završetka } \\
\text { školovanja (t-test) } \\
\begin{array}{c}1=u \text { Vukovarsko-srijemskoj županiji } \\
2=\text { izvan Vukovarsko-srijemske županije }\end{array}\end{array}$ \\
\hline \multicolumn{2}{|c|}{ Kvaliteta usluga i sadržaja } & $1(3,42)>2(3,23)$ \\
\hline \multicolumn{2}{|c|}{ Kvaliteta stanovanja } & $1(3,87)>2(3,72)$ \\
\hline \multicolumn{2}{|c|}{ Prirodni okoliš } & $1(3,62)>2(3,48)$ \\
\hline \multicolumn{2}{|c|}{ Kvaliteta susjedstva } & $1(3,83)>2(3,61)$ \\
\hline \multicolumn{2}{|c|}{ Sigurnost } & $1(3,95)>2(3,76)$ \\
\hline \multicolumn{2}{|c|}{ Prometna povezanost } & $1(3,75)>2(3,41)$ \\
\hline \multicolumn{2}{|c|}{ Zadovoljstvo infrastrukturom } & - \\
\hline \multicolumn{2}{|c|}{ Mogućnost zapošljavanja } & $1(2,24)>2(1,98)$ \\
\hline \multirow{10}{*}{ 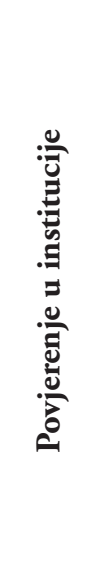 } & Lokalne vlasti & $1(2,65)>2(2,50)$ \\
\hline & Pravosude & - \\
\hline & Policija & - \\
\hline & Političke stranke & - \\
\hline & Vojska & $1(4,00)>2(3,67)$ \\
\hline & Crkva & $1(3,88)>2(3,42)$ \\
\hline & Obrazovne institucije & $1(3,55)>2(3,39)$ \\
\hline & Zdravstvene institucije & - \\
\hline & Mediji & - \\
\hline & Udruge građana & - \\
\hline
\end{tabular}

Napokon, učenici koji bi u budućnosti živjeli na području županije nešto pozitivnije gledaju na mogućnosti zapošljavanja te imaju veće povjerenje u četiri institucije, i to one lokalne vlasti, vojsku, crkvu i obrazovne institucije. $\mathrm{Na}$ taj način jasne razlike postoje i u aspektu nazvanom strukturno društveno okružje. 
Dobiveni rezultati, potvrđuju postavljenu hipotezu prema kojoj oni koji više vrednuju kvalitetu života u županiji, u većoj mjeri vide i svoju budućnost u njoj.

Pokazalo se također da ne postoji statistički značajna razlika u pogledu želje da se nakon školovanja živi na području županije ili negdje drugdje među ispitanicima različitih teritorijalnih skupina. Dakle, niti kada se promatraju odgovori ispitanika sa županjskog, vinkovačkog i vukovarskog područja niti kada se isto čini ovisno o veličini naselja u kojima žive, nisu dobivene značajne razlike prema njihovim migracijskim aspiracijama. To, međutim, znači da i ispitanici iz najmanjih naselja pokazuju u velikoj mjeri želju da nakon školovanja isele s područja županije. Dakle, kada su u pitanju ispitanici iz naselja manjih od 4000 stanovnika njih 37,4\% bi ih voljelo živjeti na području županije, $31,6 \%$ bi ih željelo živjeti negdje drugdje u Hrvatskoj te 31\% negdje u inozemstvu. Problem je u tome što se zadržavanje mladih s područja županije u većim županijskim centrima spominje kao važan moment u procesu promjene negativnih demografskih trendova, ali se pokazuje da veći županijski gradovi trenutno nemaju značajnu privlačnu moć za one iz manjih sredina.

Važno je, također, naznačiti da se, ukupno gledajući, iz dobivenih rezultata ne može zaključiti da ambiciozniji učenici pokazuju veću sklonost odlasku od manje ambicioznih. Naime, dvije varijable koje bi mogle na to ukazivati nisu bile statistički značajno povezane $s$ varijablom želje za životom negdje izvan županije nakon školovanja. Radi se o varijablama školskog uspjeha i planiranja nastavka školovanja nakon završetka srednje škole.

U istraživanju su uz to obrađeni i stavovi mladih o tome kako će se živjeti u mjestu njihova stanovanja za pet godina. Rezultati su prikazani u Tablici 6 .

Tablica 6. Procjena kako će se za pet godina živjeti u mjestu u kojem ispitanici stanuju

\begin{tabular}{|l|c|}
\hline \multicolumn{2}{|c|}{ Za pet godina će se živjeti... } \\
\hline ...znatno lošije nego danas & $15,5 \%$ \\
\hline ...nešto lošije nego danas & $22,9 \%$ \\
\hline ...otprilike jednako kao i danas & $37,2 \%$ \\
\hline ...nešto bolje nego danas & $20,0 \%$ \\
\hline ...znatno bolje nego danas & $4,40 \%$ \\
\hline M & 2,75 \\
\hline SD & 1,08 \\
\hline
\end{tabular}

Kada su u pitanju očekivanja kako će se na području Vukovarsko-srijemske županije živjeti za pet godina, među mladima vlada blagi pesimizam. Najveći broj njih misli da će se živjeti otprilike jednako kao i danas, a nešto je veći broj onih koji misli da će se živjeti lošije od onih koji misle da će se živjeti bolje. Kada se ovi rezultati dovedu u vezu $s$ rezultatima koji pokazuju želju mladih za odlaskom ili ostankom na području županije utvrđeno je da postoji povezanost. Naime, oni koji bi željeli ostati živjeti na području županije statistički značajno više ocjenjuju kvalitetu života $(M=2,91, S D=1,07)$ u od- 
nosu na one koji bi radije živjeli negdje drugdje ( $\mathrm{M}=2,66, \mathrm{SD}=1,07 ; \mathrm{t}=2,97, \mathrm{p}=0,003)$. Međutim, čak i među onima koji bi rado živjeli na području Vukovarsko-srijemske županije, kako se može ocijeniti i iz vrijednosti aritmetičke sredine, nema previše očekivanja u bolju budućnost. Istovremeno, utvrđena je statistički značajna povezanost dimenzije kvalitete života s varijablom očekivanja kako će se živjeti u budućnosti, pri čemu je smjer korelacije očekivan. Dakle, mladi koji ocjenjuju kvalitetu života nešto pozitivnijom, optimističniji su u pogledu budućnosti. Međutim, treba reći da pri tome nisu dobivene visoke korelaciju. Nešto veća, ali opet samo srednja korelacija, dobivena pri testiranju povezanosti osjećanja sigurnosti i očekivanja od budućnosti $(0,308)$, dok je u ostalim slučajevima korelacija niska, dakle, između 0,1 i 0,3 .

Dobivene rezultate zanimljivo je povezati s rezultatima istraživanja kvalitete života provedenog 2006. (Japec i Šućur, 2007), prema kojima su stanovnici Vukovarsko-srijemske županije, uz one iz Karlovačke i iz Šibensko-kninske, najmanje optimistični po pitanju pogleda na budućnost. Iz Vukovarsko-srijemske županije se tada $62 \%$ ispitanika u potpunosti ili djelomično složilo s tvrdnjom „Optimistično gledam na budućnost“, dok se s istom tvrdnjom složilo $82 \%$ ispitanih iz grada Zagreba. Isto istraživanje pokazalo je također da se stanovnici Vukovarsko-srijemske županije ne izdvajaju posebno po nezadovoljstvu kada je u pitanju odnos prema primjerice obrazovnim ili zdravstvenim ustanovama, niti se izdvajaju po nezadovoljstvu pojedinim stambenim aspektima. Ono u čemu su stanovnici Vukovarsko-srijemske županije pak prednjačili bio je osjećaj otuđenosti. ${ }^{6}$ Uvidom u tvrdnje putem kojih se ova dimenzija mjerila čini se da se upravo radi o povjerenju u šire društvene odnose, odnosno društveni poredak u kojem se događaju napredovanja i uspjeh, kao i teškoće koje stoje na putu istom. U tom kontekstu mogu se promatrati i rezultati istraživanja prezentirani u ovom radu. Naime, nezadovoljstvo mladih koncentrirano je upravo u onim dimenzijama koje se tiču napredovanja i društvenog uspjeha. Oni imaju teškoća sa strukturnim društvenim okružjem, dakle, onim koji bi trebao ponuditi profesionalni i radni uspjeh, te institucijama koje bi mogle i morale osigurati transparentnije napredovanje u društvu, kao što su pravosuđe i različite političke institucije.

U tom kontekstu izostaje njihov optimizam u budućnost kraja u kojem žive, a kod velikog broja njih pojavljuje se želja da u budućnosti žive negdje drugdje.

\section{ZAKLJUČAK}

U suvremenom svijetu broj se migranata konstantno povećava zbog čega i istraživanja koja se bave stavovima prema migriranju te pitanjima motivacije za migriranje različitih populacija dobivaju na značaju. Istraživanje provedeno na učenicima trećih i četvrtih

6 Ovaj se osjećaj u istraživanju iz kojeg su rezultati preuzeti mjerio putem sljedećih pet varijabli: ne gledam optimistično na budućnost, kako bi napredovao u današnje vrijeme čovjek je prisiljen raditi stvari koje nisu ispravne, osjećam se isključenim iz društva, za uspjeh je važnija sreća nego naporan rad, Život je danas postao toliko kompliciran da se u njemu jedva snalazim. 
razreda srednjih škola pokazao je da bi tek trećina njih željela nakon završetka školovanja živjeti na području županije dok je njih gotovo dvije trećine sklono iseljavanju, bilo u druge krajeve Hrvatske bilo u inozemstvo. Autori istraživanja o stavovima mladih s područja posebne državne skrbi provedenog 1999. zaključili su kako odgovor na pitanje „jesu li mladi najvećim problemom zajednice ili njezinim (dragocjenim) potencijalom, ponajprije ovisi o sposobnosti same zajednice da uspješno upravlja vlastitim razvitkom u kojem navlastitu ulogu imaju mlađe skupine“ (Raboteg-Šarić i Rogić, 2002:6). Stoga je polazište za pisanje ovog rada bilo pružanje odgovora na pitanje kako mladi procjenjuju ono što u materijalnom i društvenom smislu nasljeđuju na području Vukovarsko-srijemske županije i kako vide njezinu budućnost. Dakle, kako se kao razlog za odlazak često navodi potraga za boljim životom smatralo se važnim u ovom radu ustanoviti postoji li povezanost između pojedinih dimenzija kvalitete života i težnje da se napusti ili ostane u mjestu stanovanja.

Pokazalo se pritom da su na području županije mladi najviše zadovoljni primarnim društvenim okolišem koji se mjerio putem dimenzija sigurnosti i susjedstva. Nešto manje zadovoljstva pokazali su prema dimenzijama materijalne baze svakodnevnog života, dakle, pri ocjeni kvalitete usluga i sadržaja, prirodnog okoliša, stanovanja, prometne povezanosti te infrastrukture.

Nezadovoljstvo je pak bilo izraženo u dimenziji strukturnog društvenog okoliša koja se mjerila povjerenjem u institucije i percepcijom mogućnosti zapošljavanja. Iz takve predodžbe nesigurnog strukturnog društvenog okružja stvara se predodžba nemogućnosti racionalnog upravljanja vlastitom budućnosti na području županije te pojačana sklonost odlasku. Zapošljavanje i zadržavanje mladog stanovništva na području županije navodi se kao jedan od razvojnih uvjeta, a mladi istovremeno svoje šanse za zapošljavanje procjenjuju dosta slabima.

U kontekstu provedenog istraživanja potvrđena je hipoteza o povezanosti percepcije kvalitete života i želje da se u budućnosti živi na području Vukovarsko-srijemske županije. Naime, ispitanici manje zadovoljni dimenzijama kvalitete usluga i sadržaja, stanovanja, prirodnog okoliša, susjedstva, sigurnosti, prometne povezanost, mogućnosti zapošljavanja, kao i oni s nešto manje povjerenja u lokalne vlasti, vojsku, crkvu te obrazovne institucije, u većoj mjeri navode da bi po završstku školovanja htjeli odseliti s područja Vukovarsko-srijemske županije.

Osim toga, ispitanici koji su izrazili želju da nakon školovanja nastave živjeti na području županije nešto optimističnije gledaju na budućnosti županije, u odnosu na one koji bi nakon školovanja radije živjeli negdje drugdje.

Napokon, usprkos tome što su utvrđene neke razlike s obzirom na mjesto življenja i ocjenu kvaliteta života u županiji, one nisu previše izražene niti su jednoznačno strukturirane, čime dobiveni podaci upućuju na potrebu razvijanja razvojne politike koja bi se mogla provoditi na području čitave županije.

Može se zaključiti da Vukovarsko-srijemskoj županiji predstoji težak zadatak podizanja kvalitete života, osobito u sferi strukturnog društvenog okoliša, kako bi se ovaj prostor mogao lakše nositi s različitim tipovima demografskih i gospodarskih kriza. 


\section{LITERATURA}

Akrap, A. (2018). Depopulacijske tendencije u Slavoniji. U: Aračić P., Šantek, F. i Ćurić, M. (ur.), Kako ide istočna Hrvatska? Demografsko stanje, prognoze i traženje izlaska iz krize Slavonije, Baranje i zapadnog Srijema (str. 39-73). Zagreb i Đakovo: Hrvatska akademija znanosti i umjetnosti i Zavod za znanstveni i umjetnički rad u Đakovu.

Beck, U. (2001). Live your own life in a Runaway world: Individualisation, Globalisation and Politics. U: Hutton, W. i Giddens, A. (ur.), Global Capitalism (str. 164174). New York: The New Press.

Božić, S. i Burić, I. (2005). Migracijski potencijal hrvatske - mikroanalitički aspekti. Migracijske i etničke teme, 21(1-2): 9-33.

Čengić, D. (2012). Razvojni potencijali Vukovarsko-srijemske županije: u potrazi za strategijom razvoja. U: Živić, D. (ur.), Vukovarsko-srijemska županija. Prostor, ljudi, identitet (str. 455-466). Zagreb i Vukovar: Institut društvenih znanosti Ivo Pilar i Vukovarsko-srijemska županija.

Eurofound, (2014). Trendovi u kvaliteti života - Hrvatska: 2007.-2012. Luxembourg: Ured za publikacije Europske unije.

Gottdiener, M. i Hutchinson, R. (2011). The new urban sociology. Boulder, CO: Westview press.

Ferriss, A. (2004). The Quality of Life Concept in Sociology, The American Sociologist, 35(3): 37-51.

Gvozdanović, A. (2014). Politički utjecaj i vrijednosti kao odrednice političkog povjerenja mladih u Hrvatskoj. Revija za sociologiju, 44(1): 5-30.

Ilišin, V., Bouillet, D., Gvozdanović, A. i Potočnik D. (2013). Mladi u vremenu krize. Prvo istraživanje IDIZ-a i Zaklade Friedrich Ebert o mladima. Zagreb: Institut za društvena istraživanja u Zagrebu i Friedrich Ebert Stiftung.

Japec, L. i Šućur, Z. (ur.) (2007). Kvaliteta života u Hrvatskoj: regionalne nejednakosti. Zagreb: Program Ujedinjenih naroda za razvoj (UNDP) u Hrvatskoj.

Karajić, N. (1992). Važnost pojedinih komponenata kvalitete života. Socijalna ekologija, 1(4): 485-499.

Klempić Bogadi, S., Podgorelec, S. i Šabijan, M. (2015). Hrvatsko selo na početku 21. stoljeća - studija slučaja općina Gornja Rijeka. Sociologija i prostor, 53(202/2): 139-161.

Lajić, I., Malnar, A. i Mišetić, R. (2018). Predmigracijsko raspoloženje maturanata četiriju najvećih hrvatskih gradova. Hrvatski geografski glasnik, 80(1): 77-98.

Miletić, G. M., Krnić, R. i Majetić, F. (2016). Susjedstvo i socijalna integracija: utjecaj lokalnih društvenih odnosa na percepciju socijalne kohezije u susjedstvu na primjeru Hrvatske. Revija za socijalnu politiku, 23(2): 215-239.

Ministarstvo regionalnog razvoja i fondova Europske unije (2018). Vrijednosti indeksa razvijenosti i pokazatelja za izračun indeksa razvijenosti prema novom modelu izračuna na lokalnoj razini (razdoblje 2014.-2016.). URL: https://razvoj.gov.hr/UserDocsImages//O\%20ministarstvu/Regionalni\%20razvoj/indeks\%20razvijenosti// 
Vrijednosti\%20indeksa\%20razvijenosti\%20i\%20pokazatelja $\% 20 \mathrm{za} \% 20 \mathrm{izra} \%$ C4\%8Dun\%20indeksa\%20razvijenosti_jedinice\%20lokalne\%20sam ouprave.pdf (31.05.2019.)

Mišetić, A., Franc, R., Miletić, G. M. i Vrselja, I. (2012). Sadašnjost i budućnost Vukovarsko- srijemske županije iz perspektive njezinih stanovnika. U: Živić, D. (ur.), Vukovarsko-srijemska županija. Prostor, ljudi, identitet (str. 439-452). Zagreb i Vukovar: Institut društvenih znanosti Ivo Pilar i Vukovarsko-srijemska županija.

Mrvica Mađarac, S. (2017). Kvaliteta života stanovništva Vukovarsko-srijemske županije kao odraz gospodarskog razvoja. Doktorska disertacija. Mostar: Sveučilište Hercegovina.

Pejaković, T. (2016). Biološki sastav i starenje stanovništva Vukovarsko-srijemske županije 1961.-2011. godine. Hrvatski geografski glasnik, 78(1): 125-158.

Peračković, K. i Rihtar, S. (2016). Materijalizam kao društvena vrijednost i poticaj namjerama iseljavanja iz Hrvatske. Migracijske i etničke teme, 32(3), 295-317.

Pilarov barometar hrvatskoga društva (2015). Zagreb: Institut društvenih znanosti Ivo Pilar. URL: http://barometar.pilar.hr (21.05.2019).

Pokos, N. (2017). Osnovana demografska obilježja suvremenog iseljavanja iz Hrvatske. Političke analize, 8(31): 16-23.

Raboteg-Šarić, Z. i Rogić, I. (2002). Daleki život, bliski rub. Zagreb: Državni zavod za zaštitu obitelji, materinstva i mladeži i Institut društvenih znanosti Ivo Pilar.

Relja, R., Reić E. I. i Čerenić, V. (2015). Potreba, mogućnosti i namjera odlaska u inozemstvo: analiza stavova studenata iz Splita $(\mathrm{RH})$ i Sarajeva $(\mathrm{BiH})$. Andragoški glasnik, 19(1-2): 1-21.

Rogić, I., Bagić, D., Požar, M. i Vedriš, M. (2008). Urbani izazovi. Infrastruktura kao razvojni izazov u većim hrvatskim gradovima. Zagreb: Siemens d.d.

Seferagić, D. (1993). Kvaliteta svakodnevnog življenja u prostoru. Prostor, 1(2-4): 223234.

Slavuj, L. (2012a). Kvaliteta života u odabranim susjedstvima Grada Rijeke. Hrvatski geografski glasnik, 74(2): 69-88.

Slavuj, L. (2012b). Objektivni i subjektivni pokazatelji u istraživanju koncepta kvalitete života. Geoadria, 17(1): 73-92.

Slavuj, L. (2012c). Prilog razumijevanju složenih faktora koji utječu na svakodnevnu kvalitetu života u susjedstvima Grada Rijeke. U: Svirčić Gotovac, A. i Zlatar, J. (ur.), Akteri drustvenih promjena u prostoru; transformacija prostora i kvaliteta života u Hrvatskoj (str. 219-234). Zagreb: Institut za društvena istraživanja.

Svirčić Gotovac, A. (2006). Kvaliteta stanovanja u mreži naselja Hrvatske. Sociologija sela, 44(171/1): 105-126.

Šundalić, A. i Barković, I. (2008). Razvojne perspektive Vukovarsko-srijemske županije u uvjetima oskudnosti socijalnoga kapitala. Društvena istraživanja, 17(1-2): 77-99.

Wertheimer-Baletić, A. (2018). Demografski procesi u Hrvatskoj i u zapadnoeuropskim zemljama - razlike, sličnosti i specifičnosti. U: Aračić P., Šantek, F. i Ćurić, M. (ur.), Kako ide istočna Hrvatska? Demografsko stanje, prognoze i traženje izlaska iz 
krize Slavonije, Baranje i zapadnog Srijema (str. 11-38). Zagreb i Đakovo: Hrvatska akademija znanosti i umjetnosti i Zavod za znanstveni i umjetnički rad u Đakovu. Živić, D. (2017). Demografsko pražnjenje Istočne Hrvatske. Političke analize, 8(31): 24-32.

Živić, D., Turk, I. i Šimunić, N. (2017). Demografske promjene u Vukovarsko-srijemskoj županiji (2001.-2014.) u zrcalu nacionalne sigurnosti. U: Cvikić, S., Žebec Šilj, I. i Bendra I. (ur.), Domovinska (i europska) sigurnost. Kriza sigurnosti i politike manipuliranja suverenitetom (str. 37-72). Zagreb: Institut društvenih znanosti Ivo Pilar. 


\title{
QUALITY OF LIFE OF YOUNG PEOPLE IN VUKOVAR- SRIJEM COUNTY IN THE CONTEXT OF CONTEMPORARY DEMOGRAPHIC CRISIS
}

\author{
Mateo Žanić, Geran Marko Miletić and Ivana Bendra
}

\begin{abstract}
Summary
This paper presents the results from an empirical research conducted among third and fourth year high school pupils in Vukovar-Srijem County. The results show that even though most of the pupils express satisfaction with their lives in general, as well as with particular dimensions of the quality of life, $64.2 \%$ still want to move out from the Vukovar-Srijem County after the completion of their education. The reasons can be found in an extremely low perception of employment possibilities in the County, as well as a low level of trust in important institutions. At the same time, our hypothesis that there will be a correlation between the quality of life and the desire to remain in the County after the completion of education has been confirmed: respondents who consistently scored higher on the dimensions of the quality of life also expressed a stronger desire to continue living in the County in the future.
\end{abstract}

Key words: quality of life, young people, Vukovar-Srijem County, migration expectations, demographic crisis

\section{LEBENSQUALITÄT DER JUNGEN LEUTE IM VUKOVAR- SRIJEM-DISTRIKT UNTER DEN BEDINGUNGEN DER ZEITGENÖSSISCHEN DEMOGRAFISCHEN KRISE}

\author{
Mateo Žanić, Geran Marko Miletić und Ivana Bendra
}

\begin{abstract}
Zusammenfassung
Die vorliegende Arbeit beruht auf Ergebnissen der Forschung, an der Schülerinnen und Schüler der dritten und vierten Klasse der mittleren Schulen in Vukovar-Srijem-Distrikt teilgenommen haben. Es wurde festgestellt, dass viele von Schülern, sogar 64,2\% von ihnen nach dem Ende der Schulung außerhalb von Vukovar-Srijem-Distrikt leben möchten, obwohl sie mit ihrem Leben und einigen Dimensionen der Lebensqualität vorwiegend zufrieden sind. Die Resultate legen nahe, dass der Grund dafür darin liegt, dass ihre Berufschancen im Distrikt sehr niedrig sind und dass sie wenig Vertrauen in wichtige Institutionen haben. Die Hypothese, dass zwischen der Bewertung der Lebensqualität und dem Wunsch, nach der Schule im Distrikt zu bleiben eine Verbindung besteht, denn die Befragten, die die Dimensionen der Lebensqualität besser bewertet haben, hatten auch einen größeren Wunsch im Distrikt zu bleiben.
\end{abstract}

Schlüsselwörter: Lebensqualität, junge Leute, Vukovar-Srijem-Distrikt, Erwartungen vom Ortswechsel, demografische Krise 